\title{
Decolorization of Erythrosine B by Rhizopus arrhizus biomass
}

\author{
Neeta A. Salvi ${ }^{1}$
}

Received: 14 March 2018 / Accepted: 10 September 2018 / Published online: 20 October 2018

(c) The Author(s) 2018

\section{Abstract}

The ability of Rhizopus arrhizus biomass for the removal of dye erythrosine B from aqueous solution was explored. The dye removal capacity of the biomass was evaluated by conducting batch tests using various parameters, viz. effect of $\mathrm{pH}$, biomass dosage, contact time, modified biomasses and initial dye concentrations. The adsorption process followed a pseudo-secondorder kinetic model suggesting chemisorption might be the rate-limiting step. The equilibrium process was found to be in good agreement with Langmuir adsorption isotherm, and maximum adsorption capacities of $355.9 \mathrm{mg} / \mathrm{g}$ and $363.6 \mathrm{mg} / \mathrm{g}$ were achieved with both waste and acid-treated fresh biomass, respectively.

\section{Graphical abstract}

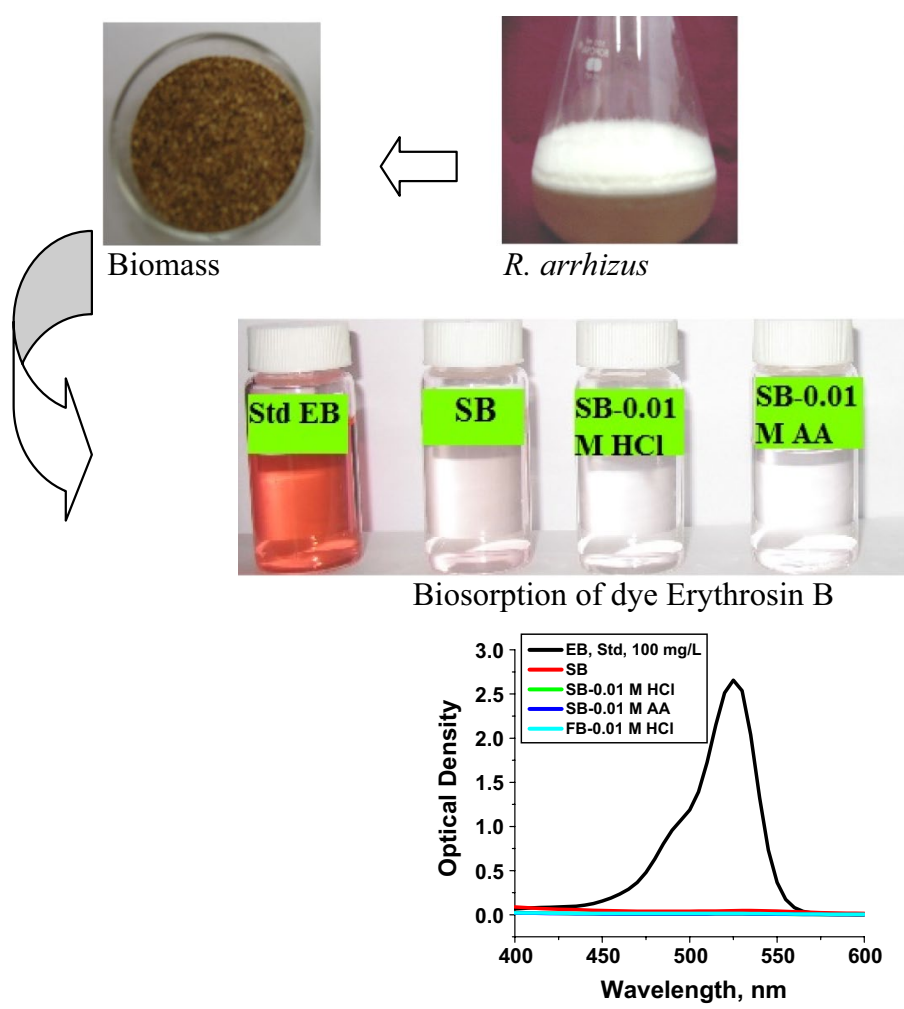

Electronic supplementary material The online version of this article (https://doi.org/10.1007/s13201-018-0800-0) contains supplementary material, which is available to authorized users.

Extended author information available on the last page of the article 
Keywords Rhizopus arrhizus biomass $\cdot$ Erythrosine B $\cdot$ Decolorization $\cdot$ Kinetic models $\cdot$ Adsorption isotherms

\section{Introduction}

Erythrosine (EB, Fig. 1) is a water-soluble cherry-pink anionic xanthene dye. It is used for colouring textiles such as wool, silk and nylon. It is also used as colourant in drugs, cosmetics, cocktails and a variety of food items (Ozsoy and Araman 1993; Tripathi et al. 2004; Virtanen et al. 1999) as well as in printing inks, lipsticks, as a biological stain, a dental plaque disclosing agent and a radio plaque medium (Desiderio et al. 1998; Mailman and Lewis 1987; Ishikawa et al. 2003). Given the extensive use of this dye, it is often found in the industrial wastewater. This highly toxic dye can cause allergic reactions in eyes, irritation of skin and upper respiratory tract, severe headaches, nausea, waterborne diseases like dermatitis, etc. It can affect thyroid functions due to presence of iodine in the molecule, which may be released upon its degradation. It can be one of the causes of atopic diseases (Uysal and Aral 1998). Consumption of this dye can also prove to be fatal, as it is carcinogenic in nature and can lead to tumours (Borzelleca et al. 1987; Sasaki et al. 2002). This visible pollutant serves as a health threat to the mankind and also can be toxic to aquatic life (Banat et al. 1996; Clarke and Anlike 1980). Knowing the toxicity of EB, its removal from wastewater has attracted attention in order to minimize the ecological and health risks. Among several physical and chemical methods, the method of adsorption onto activated carbon has been found to be superior but uneconomical as its regeneration and reactivation procedures are expensive. (Hu and Srinivasan 2001; Chakraborty et al. 2005; Rozada et al. 2003) On the other hand, its photochemical and biochemical degradation too is not recommended due to formation of toxic by-products (Tonogai et al. 1978).

Waste fungal Rhizopus arrhizus biomass has been successively used for removal of azo dyes from aqueous solution (Salvi and Chattopadhyay 2017). As an extension of this study, the present work was aimed at studying the adsorption behaviour of dye EB onto this spent biomass. The proficiency of the said biomass for the removal of toxic dye EB from aqueous solution was performed in order to develop an eco-friendly and economic method.

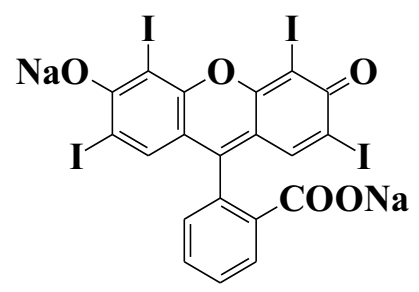

Fig. 1 Chemical structure of the dye erythrosine B
The effect of various parameters such as $\mathrm{pH}$, biomass dosage, contact time, various modifications to the biomass and initial dye concentration were studied, and results obtained have been presented in this communication.

\section{Materials and methods}

\section{Dye}

Erythrosine B was obtained from M/s Merck. It is listed in the US as FD\&C Red No. 3, in the EU as E 127 and also in many other countries as a food colouring dye.

\section{Biosorbents}

Spent biomass: The spent $R$. arrhizus biomass referred as SB (1) in this paper (a by-product from the biotransformation studies, Salvi and Chattopadhyay 2017) was washed with distilled water, boiled in acetone, squeezed and dried in the oven at $100{ }^{\circ} \mathrm{C}$ till constant weight. It was then ground to powder and sieved through a standard sieve to obtain uniform size of biomass $(420 \mu)$ which was used for biosorption studies.

Fresh biomass: Grown (72 h) R. arrhizus fungal active biomass was harvested, washed with distilled water, boiled in acetone, squeezed, dried and then ground to powder using a mortar and a pestle and sieved to obtain uniform size $(420 \mu)$ and referred as fresh biomass, FB (10).

Modified biomasses: SB and FB (2.5 g) were agitated with $250 \mathrm{ml}$ of various solutions (details mentioned below) for $6 \mathrm{~h}$ on rotary shaker $(100 \mathrm{rpm})$. After each chemical pre-treatment, the biomass was washed with distilled water until the $\mathrm{pH}$ was close to neutral, dried in the oven to a constant weight and referred as modified biomasses as follows: SB-0.1 M HCl (2) [SB treated with $0.1 \mathrm{M}$ $\mathrm{HCl}$; $\mathrm{SB}-0.01 \mathrm{M} \mathrm{HCl}(3)$ [SB treated with $0.01 \mathrm{M} \mathrm{HCl}$; SB-0.1 M AA (4) [SB treated with $0.1 \mathrm{M}$ Acetic acid]; SB-0.01 M AA: (5) [SB treated with $0.01 \mathrm{M}$ Acetic acid]; SB-0.01 M NaOH (6) [SB treated with $0.01 \mathrm{M} \mathrm{NaOH}$ ]]; SB-10\% HCHO/DW (7) [SB treated with 10\% HCHO/ DW]; SB-10\% HCHO/0.1 M HCl (8) [SB treated with $10 \%$ $\mathrm{HCHO} / 0.1 \mathrm{M} \mathrm{HCl}$; $\mathrm{SB}-10 \% \mathrm{HCHO} / 0.1 \mathrm{M} \mathrm{NaOH}$ (9) [SB treated with $10 \% \mathrm{HCHO} / 0.1 \mathrm{M} \mathrm{NaOH}] ; \mathrm{FB}-0.01 \mathrm{M} \mathrm{HCl}$ (11) [FB treated with $0.01 \mathrm{M} \mathrm{HCl}$ ]. These biomasses were used as low-cost adsorbents for the removal of EB dye from aqueous solution.

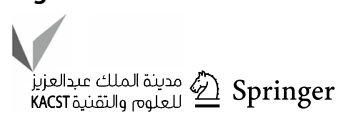




\section{Preparation of dye solution}

The stock solution (2000 $\mathrm{mg} / \mathrm{L}$ ) of dye EB was prepared in distilled water and diluted to get the desired concentration range from 50 to $2000 \mathrm{mg} / \mathrm{L}$ dye solution.

\section{Instrumentation}

Agitation was carried out on DBK-digital orbital shaker. The UV absorbance was measured on Helios $\alpha$ Spectronic Unicam spectrophotometer. The elemental analyzer, Vario Micro Cube, Elementar, Germany, was used for elemental analysis. The IR spectra were recorded on FTIR-4100 model, Jasco, Japan. The optical images were captured with a charge-coupled device, Axiocam MRC (Zeiss), camera at $600 \times$ and $1500 \times$ (oil immersion) magnification on Carl Zeiss Axioscop microscope.

\section{Batch experiments}

Laboratory batch sorption study was carried out using different variables such as effect of $\mathrm{pH}$, ionic strength, modified biomass, biomass dose, contact time and initial dye concentration to evaluate the biosorption efficiency of the biomass for removal of EB dye. The experiment was performed in a $100-\mathrm{ml}$ conical flask containing $25 \mathrm{ml}$ dye solution at room temperature $\left(24 \pm 2{ }^{\circ} \mathrm{C}\right)$. The required amount of biomass was added to the flask and agitated on a rotary shaker $(100 \mathrm{rpm})$ for a desired time period. The aqueous layer was filtered through filter paper, initial few $\mathrm{ml}$ were discarded and the absorbance of the aqueous phase was measured at dye maxima $\lambda_{\max } 525 \mathrm{~nm}$. The measured absorbance values of solutions before and after equilibrium were used to calculate the per cent colour removal (\% CR) by the biomass using Eq. (1) where Ai and Af are the initial and final absorbance of the dye. Data represent an average of three independent experiments.

$\% \mathrm{CR}=[(\mathrm{Ai}-\mathrm{Af}) / \mathrm{Ai}] \times 100$

The amount of dye adsorbed on adsorbent at equilibrium $(q, \mathrm{mg} / \mathrm{g})$ was calculated from Eq. (2) where $q$ is the dye uptake $(\mathrm{mg} / \mathrm{g}), V(\mathrm{~L})$ is the volume of dye solution, $\mathrm{Ci}$ and $\mathrm{Cf}$ are the initial and final concentration of dye in $\mathrm{mg} / \mathrm{L}$ and $M$ is the dry weight of the biomass in $\mathrm{g}$.

$q=(\mathrm{Ci}-\mathrm{Cf}) V / M$

\section{Adsorption kinetics}

In batch experiments the rate of sorption of a dye on the biomass was evaluated using different kinetic models: the pseudo-first-order, pseudo-second-order kinetics and intraparticle diffusion models. The pseudo-first-order Lagergren model (Lagergren 1898) is expressed by the Eq. (3) where $q$ and $q t(\mathrm{mg} / \mathrm{g})$ are the amount of dye adsorbed at equilibrium time and at time $t(\mathrm{~min})$, respectively. The Lagergren rate constant of the pseudo-first-order adsorption, $k_{1}(\mathrm{mg} / \mathrm{g} \mathrm{min}$ ), is calculated from the slope and $\log q$ from the intercept of the plot $\log (q-q t)$ against $t$.

$\log (q-q t)=\log q-\left(k_{1} / 2.303\right) t$

The pseudo-second-order kinetic model developed by Ho et al. (Ho and McKay 1999) is expressed by Eq. (4) where $\mathrm{t}$ is the contact time (min), $q$ and $q t(\mathrm{mg} / \mathrm{g}$ ) are amounts of dye adsorbed at equilibrium and at time $t, k_{2}$ is the pseudosecond-order constant ( $\mathrm{g} / \mathrm{mg} \min )$ and $k_{2} q^{2}=\mathrm{h}$ is the initial adsorption rate ( $\mathrm{mg} / \mathrm{g} \mathrm{min})$. The second-order rate constant $k_{2}$ and $q$ were calculated from the intercept and slope of the plot of $t / q$ against $t$.

$t / q t=1 / k_{2} q^{2}+t / q$

The intra-particle diffusion model (Weber and Morris $1963)$ is expressed by the Eq. (5) where $q t(\mathrm{mg} / \mathrm{g})$ is the amount of dye adsorbed, $\mathrm{kp}\left(\mathrm{mg} / \mathrm{g} \mathrm{min}{ }^{1 / 2}\right)$ is a rate constant and $C(\mathrm{mg} / \mathrm{g})$ is the intra-particle diffusion constant. A plot of qt and the square root of time gives the rate constant (slope of the plot) and the intra-particle diffusion constant, i.e., intercept of the line which is directly proportional to the boundary layer thickness.

$q t=\mathrm{kp} t^{1 / 2}+C$

\section{Adsorption isotherms}

The experimental equilibrium data were analysed using Langmuir (Langmuir 1918) and Freundlich (Freundlich 1906) models. The linear form of Langmuir isotherm is represented by the Eq. (6) where $\mathrm{Cf}(\mathrm{mg} / \mathrm{L})$ is the concentration of dye remaining in the solution at equilibrium, $q(\mathrm{mg} / \mathrm{g})$ is the amount of dye adsorbed per unit weight of biomass at equilibrium, $q m(\mathrm{mg} / \mathrm{g})$ is the maximum sorption capacity corresponding to monolayer sorption on the surface and $K_{\mathrm{L}}(\mathrm{L} / \mathrm{g})$ is a Langmuir constant indicating affinity of dye towards the biomass.

$\mathrm{Cf} / q=1 / q m K_{L}+\mathrm{Cf} / q m$

$R_{\mathrm{L}}$ is a dimensionless separation factor (McKay et al. 1982) which is an essential characteristic of Langmuir equation defined by the Eq. (7) where $\mathrm{Ci}(\mathrm{mg} / \mathrm{L})$ is the initial dye concentration. The value of $R_{\mathrm{L}}$ indicates the type of isotherm to be either unfavourable $\left(R_{\mathrm{L}}>1\right)$, linear $\left(R_{\mathrm{L}}=1\right)$, favourable $\left(0<R_{\mathrm{L}}<1\right)$ or irreversible $\left(R_{\mathrm{L}}=0\right)$.

$R_{\mathrm{L}}=1 / 1+K_{\mathrm{L}} \mathrm{Ci}$

The linear form of Freundlich isotherm is shown by the Eq. (8) where $K_{\mathrm{F}}(\mathrm{mg} / \mathrm{g}$ ) and $1 / n$ (dimensionless) are Freundlich isotherm constants indicating the adsorption capacity and the adsorption intensity, respectively, and also indicates the favourability of the adsorption process. 
$\log q=\log K_{\mathrm{F}}+1 / n \log \mathrm{Cf}$

\section{Effect of salt concentration}

The experiment was carried out using $100 \mathrm{mg} / \mathrm{L}$ dye solution on SB $(100 \mathrm{mg})$ in the presence of salt with different concentration, $0-10 \% \mathrm{w} / \mathrm{v}$ for $2 \mathrm{~h}$ at room temperature. The extent of bisorption was assayed by spectrophotometer.

\section{Desorption studies}

Several dye-loaded biomass samples were obtained from the sorption experiments with dye EB $(100 \mathrm{mg} / \mathrm{L})$ on SB $(100 \mathrm{mg})$ under optimized condition. The dye-loaded biomasses were then agitated separately with $25 \mathrm{ml}$ distilled water and aqueous solutions of $0.1 \mathrm{M} \mathrm{HCl}, 0.1 \mathrm{M} \mathrm{NaOH}$ and $0.1 \mathrm{M} \mathrm{NaCl}$ for $30 \mathrm{~min}$. The cell debris was removed by filtration, and the \% colour desorption was estimated by spectrophotometer.

\section{Biomass surface characterization}

The surface characterization of the biomass was done as described in the previous report (Salvi and Chattopadhyay 2017, Supplementary information).

\section{Results and discussion}

\section{Effect of influencing parameters on dye removal}

The effect of adsorbent dose on the removal of dye EB was investigated by varying the biomass dose (SB) from 25 to $200 \mathrm{mg}$. From Fig. 2, it was revealed that the \% removal efficiency of SB increased significantly with increase in

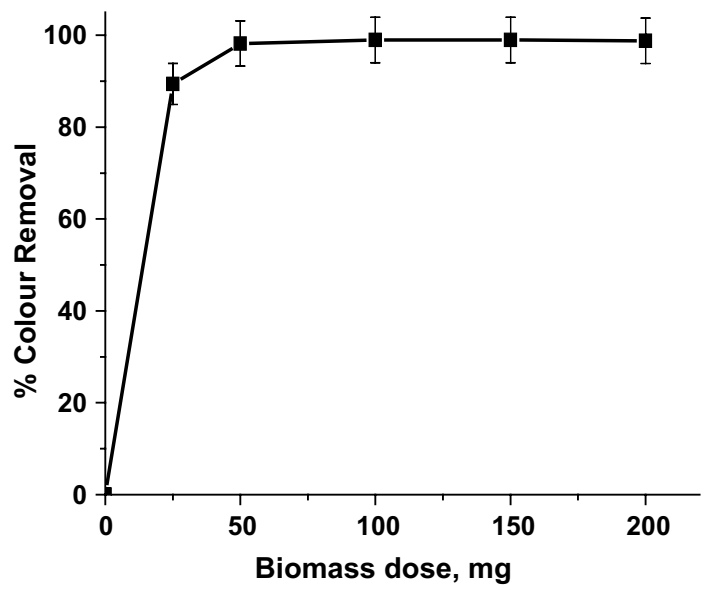

Fig. 2 Effect of biomass dose on removal of EB (dye concentration: $100 \mathrm{mg} / \mathrm{L}, 4 \mathrm{~h}$ ) the biomass dose. This might be due to greater surface area and the availability of more adsorption sites. The optimum dose was found to be between 100 and $150 \mathrm{mg}$ of SB. As a result, $100 \mathrm{mg}$ of biomass was selected for further biosorption studies.

The $\mathrm{pH}$ is an important parameter since it affects the activities of functional groups present on the biomass surface and also influences the availability of dye molecules for biosorption process. The decolorization of aqueous EB solution was carried out at $\mathrm{pH}$ range $2-10$. From Fig. 3, it was observed that the $\%$ dye adsorbed on spent $R$. arrhizus biomass was nearly the same in the $\mathrm{pH}$ range $4-8$. The maximum \% removal was 98.7 at $\mathrm{pH} 6-8$. This might be due to increase in the electrostatic attraction between negatively charged dye anions and positive biosorbent surface binding sites which favoured the removal of dye anions. As a result, further biosorption studies were carried out at the natural aqueous dye solution $\mathrm{pH}(\mathrm{pH} \sim 7.0)$.

The dye in wastewater is accompanied by a large amount of salt, which likely interferes with the dye biosorption (Karcher et al. 2001). The effect of salt concentration $(\mathrm{NaCl}$, $0-10 \%$ ) on biosorption of dye EB (conc. $100 \mathrm{mg} / \mathrm{L}$ ) onto SB (100 mg) was tested. From Fig. 4, it was noticed that an increase in the ionic strength of solution showed almost negligible effect on \% colour removal of dye EB, indicating that $\mathrm{Cl}^{-}$ions did not compete strongly with the binding adsorption sites on the biomass. An elevated ionic strength also did not significantly interfere with the binding of dye molecule to the biomass. Thus, indicating the coexistence of salt in solution played a positive role in adsorption of EB onto spent $R$. arrhizus biomass (Tang et al. 2000).

The batch sorption studies were conducted using SB $(100 \mathrm{mg}$ ) over different time periods (from 5 to $180 \mathrm{~min}$ ) using three different initial dye concentrations (50, 100 and $200 \mathrm{mg} / \mathrm{L}$ ) at natural $\mathrm{pH}$. The results are summarized in

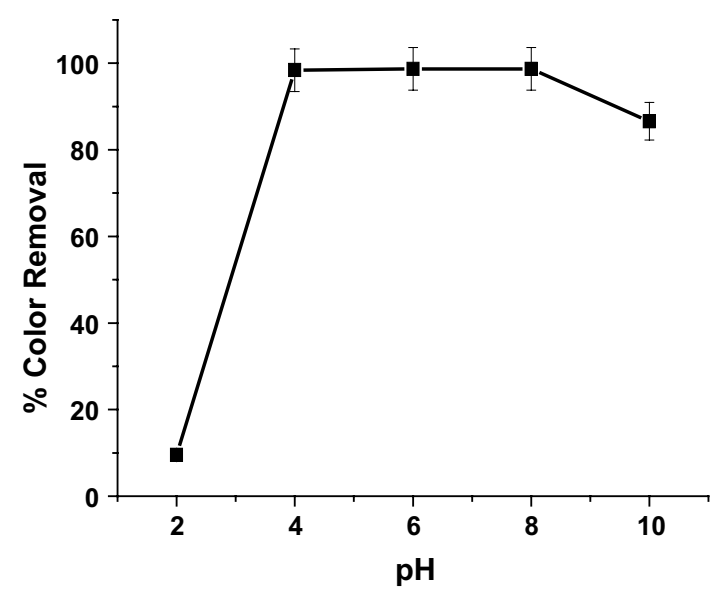

Fig. 3 Effect of $\mathrm{pH}$ on removal of $\mathrm{EB}$ (dye concentration: $100 \mathrm{mg} / \mathrm{L}$, biomass: $100 \mathrm{mg}, 4 \mathrm{~h}$ ) 


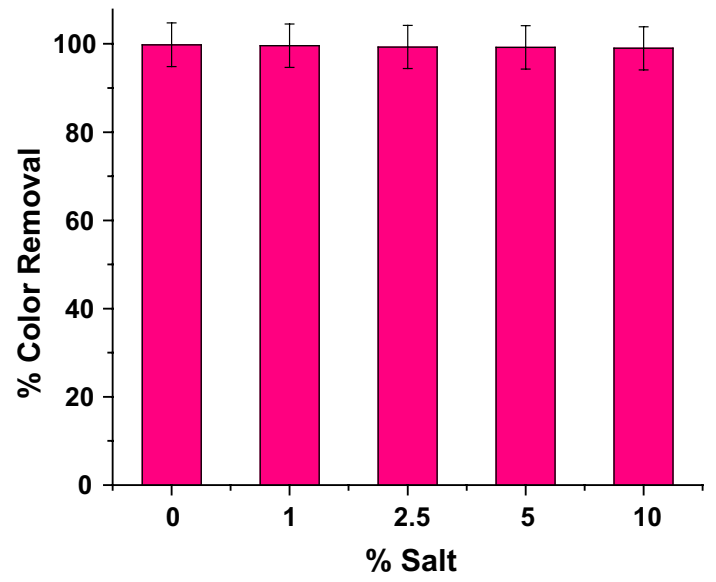

Fig. 4 Effect of salt on removal of EB (dye concentration: $100 \mathrm{mg} / \mathrm{L}$, biomass: $100 \mathrm{mg}, 4 \mathrm{~h}$ )

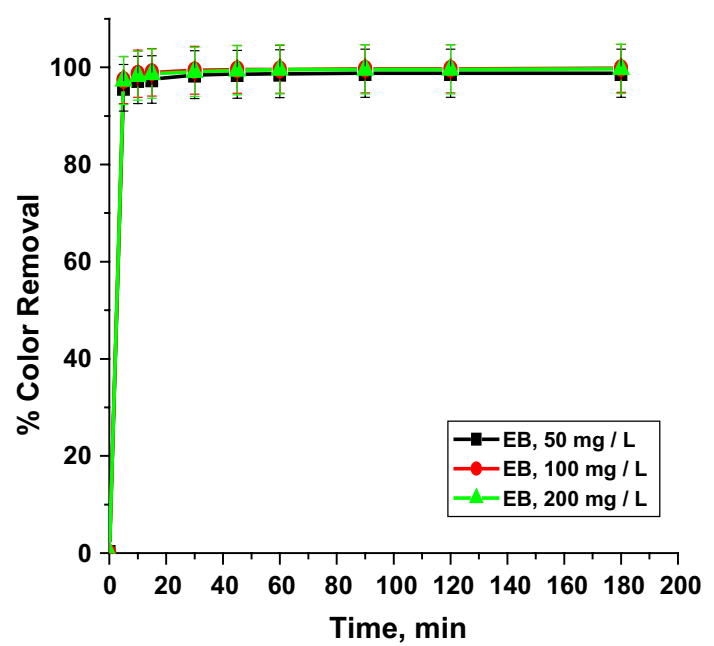

Fig. 5 Effect of contact time on removal of EB (dye concentration: 50, 100 and $200 \mathrm{mg} / \mathrm{L}$, biomass: $100 \mathrm{mg}$ )
Fig. 5. The EB uptake had a sharp increase at the beginning of the adsorption. After 10 min, $97 \%$ of adsorption was observed in all the three initial dye concentrations. The initial high adsorption rate was apparently attributed to the abundance of adsorption sites on the biomass probably via surface functional groups available for dye adsorption. So that dye molecules interacted easily with these sites and the sorption gradually increased till equilibrium. The sorption became less efficient with the gradual occupancy of these sites, remained almost constant and attained a plateau. The plot specified that equilibrium time for all the concentrations was independent of initial dye concentration, and within $1 \mathrm{~h}$ maximum adsorption was attained by the biomass. For confirmed sufficient saturation, contact time was further extended and experiments were carried out for $2 \mathrm{~h}$.

The efficiency of biomass can be manipulated by surface modification of fungal biomass using acid, base, salt, etc. The cost of this approach is typically lower because the modification agents used are less expensive. The effect of various modified biomasses on biosorption of $\mathrm{EB}$ appeared in Fig. 6. It was observed that, biosorption of dye EB on SB was almost similar to that of acid-treated biomasses, viz. SB-0.1 M HCl, SB-0.01 M HCl, SB-0.1 M AA, SB-0.01 M $\mathrm{AA}, \mathrm{SB}-10 \% \mathrm{HCHO}$ in DW, SB-10\% $\mathrm{HCHO}$ in $0.1 \mathrm{M} \mathrm{HCl}$ and FB- $0.1 \mathrm{M} \mathrm{HCl}$. This might be due to the binding of $\mathrm{H}^{+}$ ions on native biomass after acid treatment and change in the surface electronegetivity which favoured the adsorption of anionic dye EB. Sorption was decreased in the alkali pretreated spent biomasses. This could be due to the formation of negative charged biomass surface may exert electrostatic repulsion between the anionic EB and the negatively charged sites on fungal biomass. Significant differences in the colour removal after decolourization process with SB, all acid-treated SB and FB-0.01 M HCl was seen when compared with the control dye solution. Therefore, for practical
Fig. 6 Effect of modified biomasses on sorption of $\mathrm{EB}$ (dye concentration: $100 \mathrm{mg} / \mathrm{L}$, biomass: $100 \mathrm{mg}, 2 \mathrm{~h}$ )
FB-0.01 M HCI

FB

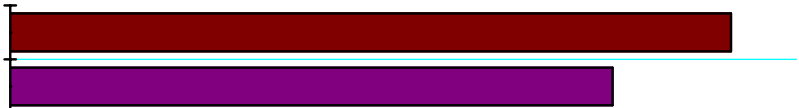

SB-10\% HCHO/0.1M NaOH

$\mathrm{SB}-10 \% \mathrm{HCHO} / 0.1 \mathrm{M} \mathrm{HCl}$ SB-10\% HCHO/DW

SB-0.01 M NaOH

SB-0.01 M Acetic acid

SB-0.1 M Acetic acid

SB-0.01 M HCl

SB-0.1 M HCl

SB

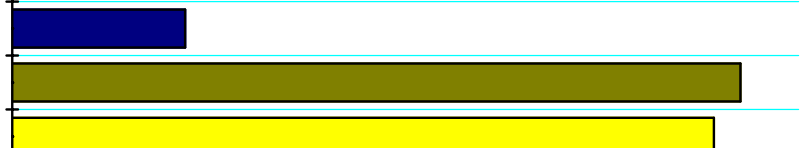

.

\section{.}

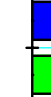

\section{.}

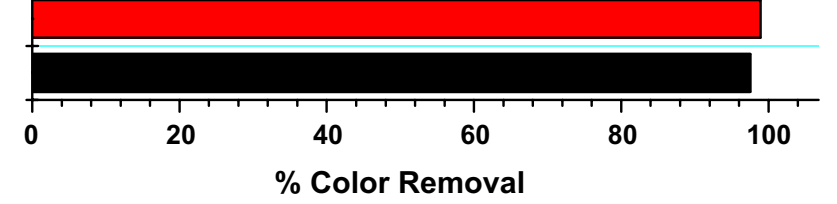

$\%$ Color Remova 
purpose further biosorption studies were carried out with SB and $\mathrm{FB}-0.01 \mathrm{M} \mathrm{HCl}$ biomass only.

As the adsorptive rate varies directly with concentration of the adsorbate, the effect of concentration of adsorbate on $\%$ colour removal was studied onto $100 \mathrm{mg}$ of SB and FB- $0.01 \mathrm{M} \mathrm{HCl}$ with the dye concentration range from 50 to $2000 \mathrm{mg} / \mathrm{L}$ at natural $\mathrm{pH}$. As shown in Fig. 7, it was observed that the \% removal efficiency decreased from 99.3 to $96.3 \%$ with increase in the initial dye concentration from 50 to $1000 \mathrm{mg} / \mathrm{L}$ and thereafter decreased drastically to $74.3 \%$ at $2000 \mathrm{mg} / \mathrm{L}$ dye concentration. The removal efficiency depended on the number of active sites present on the biomass surface, and at fixed dose of biomass the numbers of active sites are limited. When the initial concentrations are increased with the same biomass dose, the active sites become fewer for adsorption, thereby decreasing the removal efficiency. At low dye concentration, the availability of sorption sites are relatively more so that dye adsorbed readily. But at high dye concentration, the available adsorption sites became saturated, causing decreased in colour removal efficiency with an increased in the dye uptake capacity which signified good efficiency of $R$. arrhizus biomass. The experimental sorption capacity $(q)$ of $R$. arrhizus biomass was found to be $\sim 250 \mathrm{mg} / \mathrm{g}$ at initial dye conc. $1000 \mathrm{mg} / \mathrm{L}$ with both the biosorbents.

\section{Kinetic modelling}

The three different kinetic models, viz. pseudo-first-order kinetic model, pseudo-second-order kinetic model and intraparticle diffusion models were applied to the experiment data with respect to three different initial dye concentrations (50, 100 and $200 \mathrm{mg} / \mathrm{L})$, and the corresponding regression coefficients for each expression were compared.

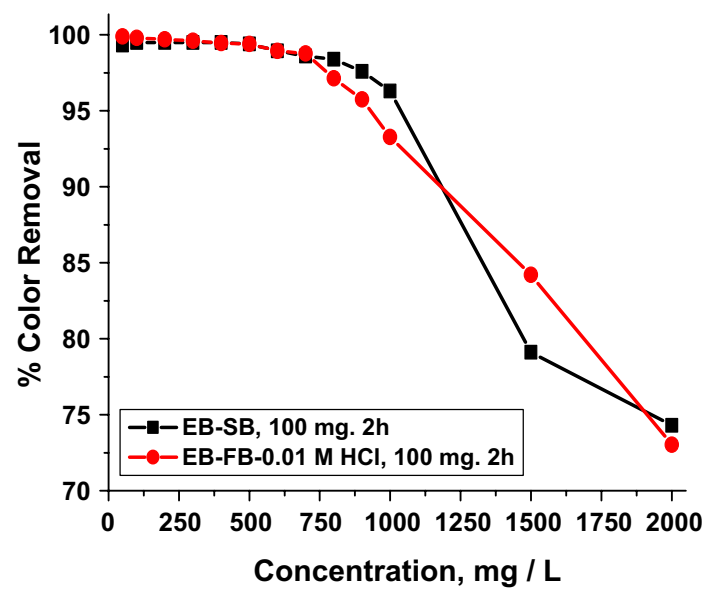

Fig. 7 Effect of dye EB concentration-biomasses SB, FB-0.01 M $\mathrm{HCl}: 100 \mathrm{mg}, 2 \mathrm{~h}$
The correlation coefficients obtained from plot of log $\left(q-q_{\mathrm{t}}\right)$ versus $t$ for pseudo-first-order kinetic model for all three different initial dye concentrations were found to be very low (data not shown). The calculated $q$ values were not in good agreement with the experimental values, indicating a poor fit of pseudo-first-order model to the experimental data.

In pseudo-second-order kinetic model the second-order rate constant $k_{2}$ and $q$ were calculated from the intercept and slope of the plots of $t / q$ against $t$. Figure 8 shows the applicability of the pseudo-second-order kinetic model to the experimental data. From Table 1, it was observed that with an increasing initial dye concentration, an increased in the equilibrium adsorption capacity, $q$ and the adsorption rate $\mathrm{h}$ occurred but the rate constant $k_{2}$, decreased. The calculated q values were much closer to the experimental data for all three initial dye concentrations. Much higher values of $R^{2}\left(R^{2}=1.0\right)$ and the calculated $q$ values for all three initial dye concentrations, confirms the applicability of the pseudo-second-order kinetic model and described that chemisorptions might be the rate-limiting step involving valence forces through sharing or the exchange of electrons between biosorbent and sorbate. Higher $h$ values indicated that the adsorption of EB from aqueous solution was very fast and therefore SB is suitably used as an effective adsorbent for the removal of EB from aqueous solution.

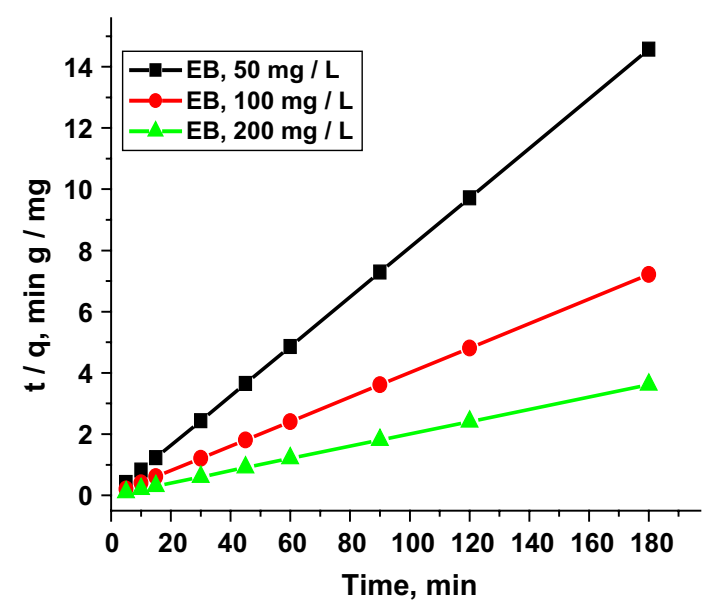

Fig. 8 Pseudo-second-order kinetic plots for

Table 1 Pseudo-second-order kinetic parameters

\begin{tabular}{lllcl}
\hline $\begin{array}{l}\text { Dye conc. } \\
(\mathrm{mg} / \mathrm{L})\end{array}$ & $q(\mathrm{mg} / \mathrm{g})$ & $K_{2}(\mathrm{~g} / \mathrm{mg} \min )$ & $h(\mathrm{mg} / \mathrm{g} \min )$ & $R^{2}$ \\
\hline 50 & 12.37 & 0.523 & 79.94 & 1 \\
100 & 24.96 & 0.309 & 193.05 & 1 \\
200 & 49.88 & 0.137 & 341.29 & 1 \\
\hline
\end{tabular}




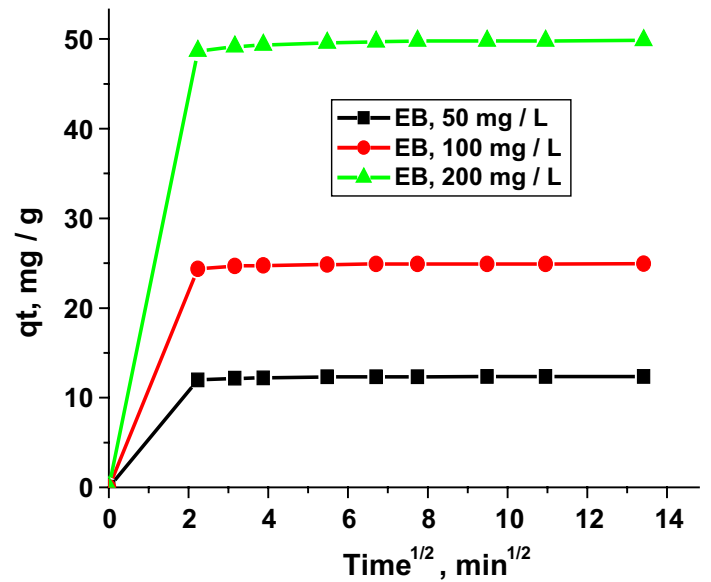

Fig. 9 Intra-particle diffusion kinetic plots for various dye EB concentration onto SB various dye EB concentration onto SB

The kinetic data was also analysed by using the intraparticle diffusion kinetic model. The plots $q t$ versus $t^{1 / 2}$ for all three dye concentrations was found to be linear (Fig. 9). All the three plots did not pass through the origin thereby signifying involvement of intra-particle diffusion kinetic model but it was not the only rate-limiting step.

\section{Adsorption isotherms}

Equilibrium adsorption isotherms describe the nature of the interaction between the adsorbate molecules and the adsorbent surface and the capacity of biomass to remove dyes under given set of conditions.

The data obtained from the influence of dye concentration on biosorption percentage at room temperature was analysed by two well-known isotherm models, viz. Langmuir and Freundlich isotherm models. These models often provide some insight into the sorption mechanisms, the surface properties and affinities of the sorbent. Applicability of these models was compared by judging the correlation coefficients (Fig. 10a, b).

Langmuir isotherm theory predicts monolayer coverage of adsorbate on the homogeneous adsorbent surface. In this model, sorption is assumed to take place at specific homogeneous sites within the adsorbent and there is no interaction among the sorbed sites. Once a dye molecule occupies a site, no further adsorption can take place at that site. The plots between $\mathrm{Cf} / q$ versus $\mathrm{Cf}$ showed a straight line confirmed the validity of the Langmuir isotherm model, with slope equal to $1 / q_{\max }$ and intercept equal to $1 /\left(K_{\mathrm{L}} q_{\max }\right)$. As summarized in Table 2, these linear isotherms displayed high regression coefficient value closer to unity $(<0.99)$ indicating good fit of experimental adsorption data with Langmuir isotherm model showing monolayer coverage of $\mathrm{EB}$ on both $\mathrm{SB}$ and $\mathrm{FB}-0.01 \mathrm{M} \mathrm{HCl}$ biomass and predicted almost similar
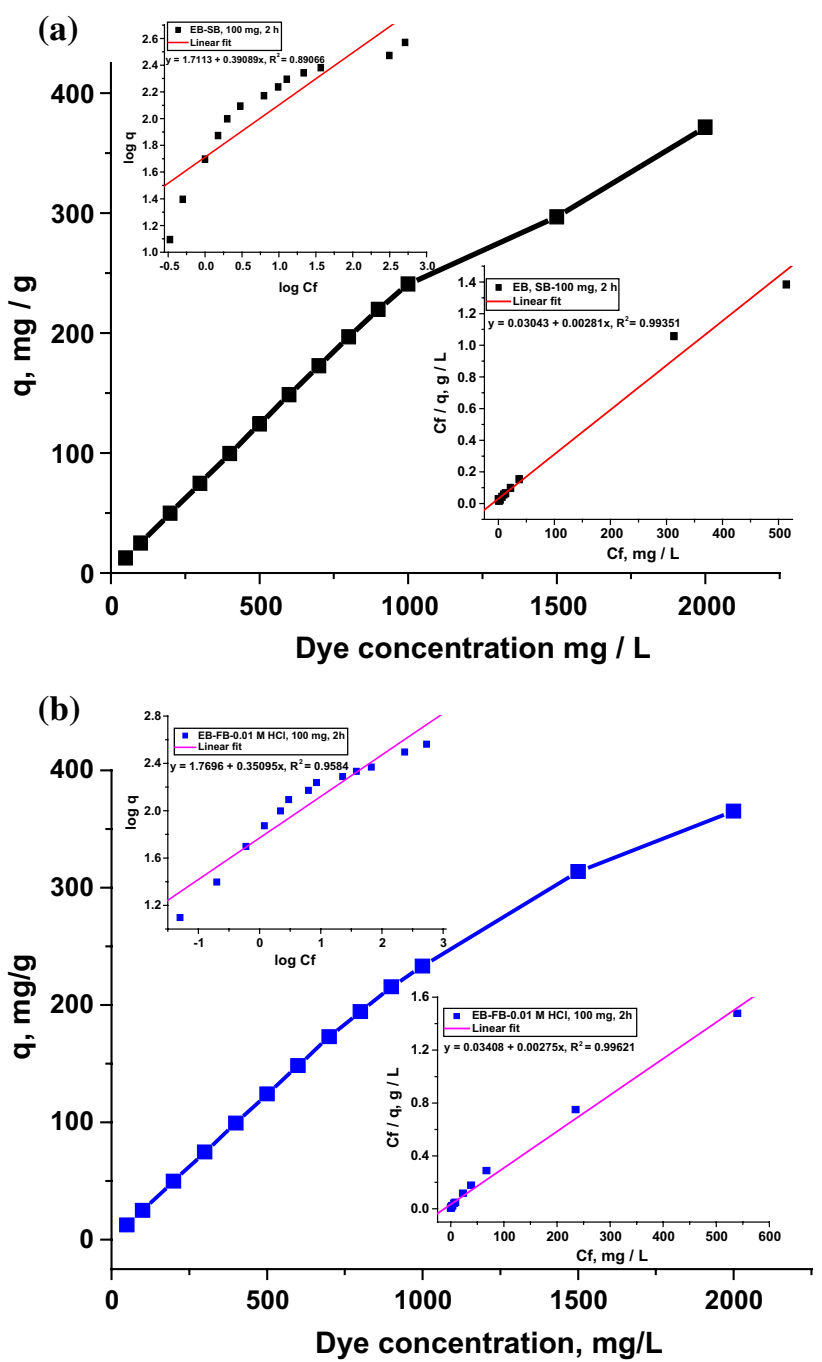

Fig. 10 a Adsorption isotherms of EB onto SB. b Adsorption isotherms of EB onto FB-0.01 M HCl

maximum sorption capacity $\left(q_{\max }\right) 355.87$ and $363.64 \mathrm{mg} / \mathrm{g}$, respectively. Indicating chemisorptions process in which a more specific binding of the adsorbate on the adsorbent is involved. For Langmuir adsorption isotherm, the separation factor, $R_{\mathrm{L}}$, a dimensionless constant is essential characteristic to investigate the dye-adsorbent system. In both the cases, $R_{\mathrm{L}}$ values were found to be positive and less than unity $\left(0<R_{\mathrm{L}}<1\right)$ indicating a highly favourable adsorption of EB under the studied conditions.

Freundlich isotherm describes heterogeneous systems and characterized by the heterogeneity factor, $K_{\mathrm{F}}$, a Freundlich isotherm constant and $1 / n$ is Freundlich exponent related to adsorption intensity. $K_{\mathrm{F}}$ gives the rough indication of capacity of the adsorbent, and $1 / n<1$ indicates the favourability of biosorption process under studied conditions. The experimental results were found to be consistent with Freundlich model. The linear plots of $\log q$ versus $\log \mathrm{Cf}$ showed that

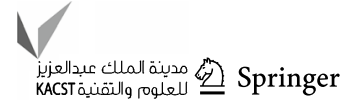


Table 2 Adsorption isotherm parameters

\begin{tabular}{|c|c|c|c|c|c|c|c|}
\hline \multirow[t]{2}{*}{ Biomass } & \multicolumn{4}{|c|}{ Langmuir adsorption isotherm } & \multicolumn{3}{|c|}{ Freundlich adsorption isotherm } \\
\hline & $q_{\max }(\mathrm{mg} / \mathrm{g})$ & $K_{\mathrm{L}}(\mathrm{L} / \mathrm{mg})$ & $R^{2}$ & $R_{\mathrm{L}}$ & $K_{\mathrm{F}}(\mathrm{mg} / \mathrm{g})$ & $1 / n$ & $R^{2}$ \\
\hline SB & 355.87 & 0.0923 & 0.994 & $0.97-0.18$ & 51.4 & 0.3909 & 0.891 \\
\hline FB-0.01 M HCl & 363.64 & 0.0807 & 0.996 & $0.91-0.19$ & 58.7 & 0.3509 & 0.958 \\
\hline
\end{tabular}

the adsorption onto SB and FB-0.01 M HCl biomass surfaces followed Freundlich isotherm model, and from the slope and intercept of the plots, the values of $\mathrm{n}$ and $K_{\mathrm{F}}$ were calculated.

Thus, the biosorption of EB onto R. arrhizus biomass was fitted with both Langmuir and Freundlich isotherm models suggesting the hybrid sorption mechanism may be due to homogeneous and heterogeneous distribution of active sites on the biomass surface. The values of $R^{2}$ were found to be less than unity which confirmed the ongoing adsorption process is favourable.

\section{Adsorption capacities of other sorbents reported in the literature}

Several others biosorbents were used for the removal of EB, and their maximum adsorption capacities cited in the literature are depicted in Table 3. The efficiency of $R$. arrhizus biomass was found to be high compared to other biosorbents except Sugarcane bagasse. Sugarcane bagasse showed good adsorption capacity of $500 \mathrm{mg} / \mathrm{g}$, under highly alkaline conditions ( $\mathrm{pH} 9.0$ ) and at high temperature, $55^{\circ} \mathrm{C}$. The adsorption was decreased to $333 \mathrm{mg} / \mathrm{g}$ with decreased in temperature to $35^{\circ} \mathrm{C}$. The removal capacities for $\mathrm{EB}$ are higher in mesoporous graphitic activated carbon prepared from Bael Tree $(576.12 \mathrm{mg} / \mathrm{g}$ ), anaerobic granular sludge activated carbon (416.66 mg/g), activated de-oiled mustard, (3043.98 mg/g at pH 3.5) which need to be processed before it can be employed as an adsorbent and clay montmorillonite $(578.03 \mathrm{mg} / \mathrm{g}$ at $\mathrm{pH} 7.5)$. The present biomass furnished maximum monolayer adsorption capacity (355.87-363.64 mg/g) at natural $\mathrm{pH} \sim 7.0$ and at ambient temperature, $24 \pm 2{ }^{\circ} \mathrm{C}$, showing the feasibility of Rhizopus arrhizus biomass as a practical alternative for dye decolorization.

\section{Desorption studies}

Desorption studies help to elucidate the mechanism of adsorption. It was observed that almost negligible amount of dye was desorbed with neutral $\mathrm{pH}$ water and acidic solutions. However, $46 \%$ of dye was desorbed with $0.1 \mathrm{~N}$ aq. $\mathrm{NaOH}$ (Fig. 11). Desorption at higher $\mathrm{pH}$ may be explained on the basis of electrostatic repulsion between the negatively charged sites on the fungal biomass and the anionic dye molecules (Namasivayam et al. 1996, 2001).

Table 3 Adsorption capacities of other sorbents reported in the literature for dye EB removal

\begin{tabular}{|c|c|c|}
\hline Sorbent & Capacity (mg/g) & References \\
\hline Spent $R$. arrhizus biomass (SB) & 355.87 (natural $\mathrm{pH}$, ambient temp.) & This work \\
\hline Fresh $R$. arrhizus biomass (FB-0.01 M HCl) & 363.64 (natural $\mathrm{pH}$, ambient temp.) & This work \\
\hline Lemon citrus peel active carbon terminalia & $296(\mathrm{pH} 4)$ & Sharifzade et al. (2017) \\
\hline Catappa endocarp prepared activated carbon & $41.49\left(30^{\circ} \mathrm{C}\right)$ & Okoye et al. (2016) \\
\hline Prosopis spicigera L. wood (PSLW) carbon & $22.88\left(30^{\circ} \mathrm{C}, \mathrm{pH} 3\right)$ & Rani et al. (2016) \\
\hline Aagrowaste pumpkin seed hulls & $16.4\left(50^{\circ} \mathrm{C}\right)$ & Apostol et al. (2016) \\
\hline Mesoporous graphitic activated carbon prepared from bael tree & 576.12 & Valliamma et al. (2015) \\
\hline Ziziphus nummularia kernel, agricultural waste & $101\left(20^{\circ} \mathrm{C}, \mathrm{pH} 7\right)$ & Mohebbi et al. (2014) \\
\hline Clay montmorillonite & $578.03(\mathrm{pH} 7.5)$ & Kaur and Datta (2013) \\
\hline Commercial active carbon & $89.3\left(40^{\circ} \mathrm{C}, \mathrm{pH} 7\right)$ & Al-Degs et al. (2012) \\
\hline Anaerobic granular sludge & 416.66 (High cost) & Apostol et al. (2012) \\
\hline Sugarcane bagasse & $500\left(55^{\circ} \mathrm{C}, \mathrm{pH} 9\right)$ & Sharma and Kaur (2011) \\
\hline Chitosan/chitin hydrogel And $\mathrm{SiO} 2$ hybrid materials & 71.27 and 131.98 & Copello et al. (2011) \\
\hline Soil from Iasi area (Romania) & 0.361 & Smaranda et al. (2010) \\
\hline Activated de-oiled mustard & $3043.98(\mathrm{pH} 3.5)$ & Jain and Sikarwar (2009) \\
\hline Bottom ash and de-oiled soya & $16.17 \& 9.52(\mathrm{pH} 2)$ & Mittal et al. (2006) \\
\hline Hen feathers & $15.43(\mathrm{pH} 3.0)$ & Gupta et al. (2006) \\
\hline Montmorillonite modified with crystal violet & 123.18 (3 ays) & Rytwo et al. (2006) \\
\hline
\end{tabular}




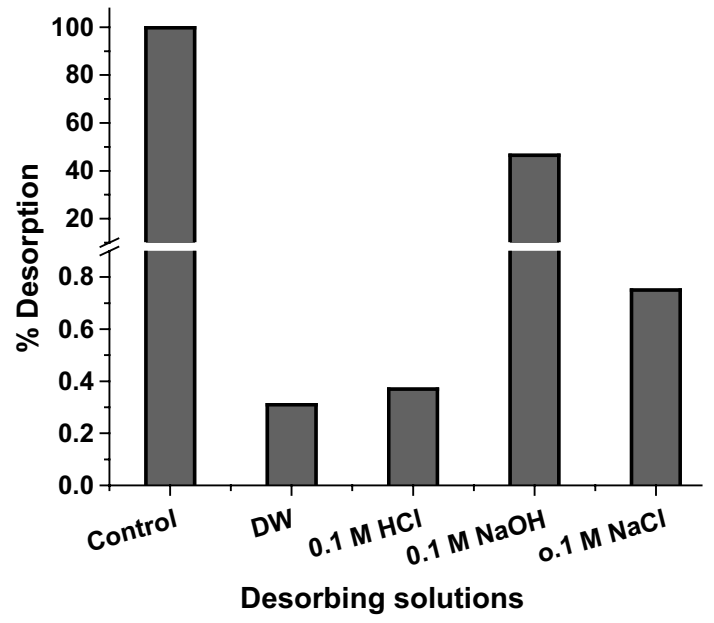

Fig. 11 Desorption of EB (dye-loaded SB-100 mg; dye concentration-100 $\mathrm{mg} / \mathrm{L}$; desorbing solutions $-25 \mathrm{ml}$; agitation time$30 \mathrm{~min}$ )

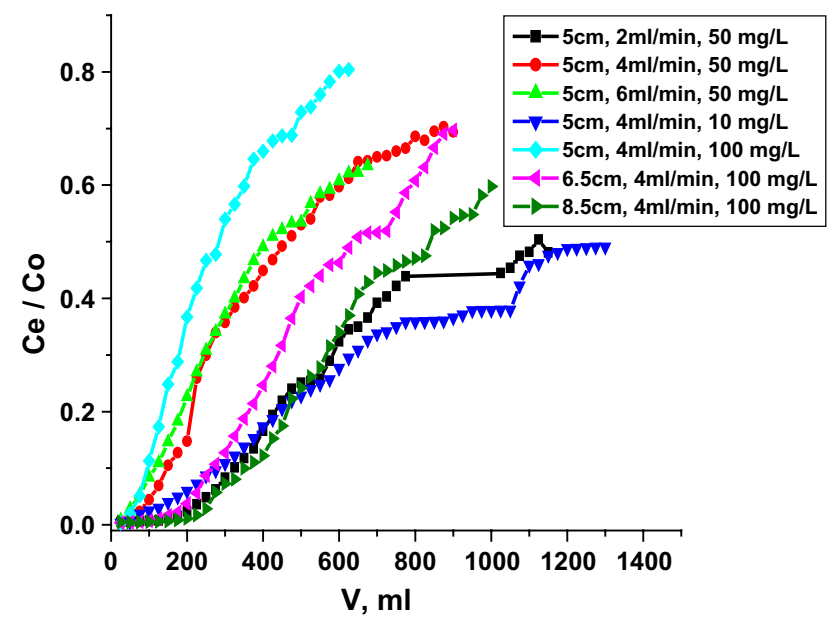

Fig. 12 Effect of various parameters on column studies on biosorption of EB using SB-effect of flow rate-2, 4 and $6 \mathrm{ml} / \mathrm{min}$, dye concentration $50 \mathrm{mg} / \mathrm{L}$, BH $5 \mathrm{~cm}$; effect of dye concentration 10,50 and $100 \mathrm{mg} / \mathrm{L}, \mathrm{BH} 5 \mathrm{~cm}$, flow rate $4 \mathrm{ml} / \mathrm{min}$; effect of bed height 5 , 6.5 and $8.5 \mathrm{~cm}$, dye concentration $100 \mathrm{mg} / \mathrm{L}$, flow rate $4 \mathrm{ml} / \mathrm{min}$ )

\section{Column studies}

The continuous flow biosorption experiments were conducted, and the results on biosorption of EB onto SB were described through the S-shaped experimental curves called breakthrough curve. Operation of the column was stopped when the effluent dye concentration exceeded $\sim 50 \%$ of its initial concentration. The breakthrough curve showed the loading behaviour of EB from the solution onto sorbent (SB) with respect to operating variables, viz. influent flow rate, dye concentration and bed height. The variation of solute concentration in the aqueous solution (normalized with the initial concentration of the dye in the solution) was plotted against eluted volume $(V, \mathrm{ml})$ and presented in Fig. 12. The amount of dye at breakthrough volume (the volume at which dye concentration in the effluent reached $1 \mathrm{mg} / \mathrm{L}$ ) and the dye concentration in the effluent at $\sim 50 \%$ of its initial concentration were calculated. The breakthrough capacity, $Q_{0.5}(50 \%)$, i.e., amount of dye retained by the biomass can be expressed as the difference between the initial amount of dye passed and the amount of dye in the effluent at its $~ 50 \%$ initial concentration. The biosorption capacity of dye in column was calculated at different flow rates, initial dye concentrations and bed heights, and results are presented in Table 4.

The effect of flow rate, $(2,4,6 \mathrm{ml} / \mathrm{min})$ of dye concentration $50 \mathrm{mg} / \mathrm{L}$ at a constant bed height of $5 \mathrm{~cm}$ was evaluated. As expected, the data showed faster and steeper breakthrough curve at higher flow rate. As the flow rate increases, the residence time in the bed decreases which resulted in lower bed utilization. Therefore, the breakthrough volume and the bed capacity will decrease with increasing flow rate. For lower value of flow rate, the contact time is longer and hence the interaction between the dye and the biomass is greater which leads to higher dye sorption. On the other hand, for higher flow rate, the contact time is shorter and the dye sorption is also lower due to lesser interact ion.

The effect of initial dye concentration, 10, 50 and $100 \mathrm{mg} / \mathrm{L}$ at flow rate $4 \mathrm{ml} / \mathrm{min}$ and at a constant bed
Table 4 Effect of various parameters on column biosorption studies of dye EB on SB

\begin{tabular}{llllll}
\hline Entry & $\begin{array}{l}\text { Flow rate }(\mathrm{ml} / \\
\text { min })\end{array}$ & $\begin{array}{l}\text { Dye conc. } \\
(\mathrm{mg} / \mathrm{L})\end{array}$ & $\begin{array}{l}\text { Bed height } \\
(\mathrm{cm})\end{array}$ & $\begin{array}{l}\text { Biosorption capacity } \\
(\mathrm{mg} / \mathrm{g} \text { at 0\% BT) }\end{array}$ & $\begin{array}{l}\text { Biosorption capac- } \\
\text { ity (mg/g at 50\% } \\
\text { BT })\end{array}$ \\
\hline 1 & 2 & 50 & 5 & 9.9 & 44.72 \\
2 & 4 & 50 & 5 & 3.7 & 17 \\
3 & 6 & 50 & 5 & 2.5 & 15.12 \\
4 & 4 & 10 & 5 & 2.9 & 9.5 \\
5 & 4 & 100 & 5 & 4.95 & 20.93 \\
6 & 4 & 100 & 6.5 & 8.3 & 34.3 \\
7 & 4 & 100 & 8.5 & 9.94 & 33.61 \\
\hline
\end{tabular}


height $5 \mathrm{~cm}$ was evaluated. The change in the initial dye concentration had a significant effect on the breakthrough curve. The larger the initial dye concentration, the faster the breakthrough indicating a lower treated volume; however, the dye loadings is larger indicating the diffusion process is concentration dependent. In addition, at lower dye concentrations the breakthrough curves were lengthened, while steeper breakthrough curve at higher concentrations signifies a lesser dye solution treatment capability. This trend indicates that the higher dye concentration could saturate the biosorbent more quickly. At lower concentration, the smaller mass transfer caused the treatment of a higher volume of dye solution during the adsorption process. Results demonstrated increase in biosorption capacity with the solute concentration.

Accumulation of dyes in fixed bed column is largely dependent on the quantity of biomass inside the column. The effect of varying the height of the bed $5,6.5,8.5 \mathrm{~cm}$ filled with SB was investigated at a constant flow rate, $4 \mathrm{ml} /$ min and inlet EB concentrations, $100 \mathrm{mg} / \mathrm{L}$. From the breakthrough profiles, it was observed that the breakthrough volumes were increased with bed heights. This might be due to increase in sorption sites with increase in the bed height leading to a larger sorption capacity of the biomass.

Thus initial concentration, flow rate and bed height significantly influenced the dye removal in the continuous column process.

\section{Conclusion}

The present study investigated the efficacy of spent fungus $R$. arrhizus for removal of dye erythrosine B from aqueous solution at natural $\mathrm{pH}$ value of the dye solution and at ambient temperature with easy operation. It furnished maximum monolayer sorption capacity $355.87 \mathrm{mg} / \mathrm{g}$ which is comparable with the maximum adsorption capacity, $363.64 \mathrm{mg} / \mathrm{g}$ obtained with $0.01 \mathrm{M} \mathrm{HCl}$-treated fresh $R$. arrhizus biomass. This observation suggested that the $R$. arrhizus biomass could be used as a low-cost, natural, safe, effective, ecofriendly and a promising source of biosorbent for industrial wastewater treatment in cleaning up dye pollution.

Acknowledgements The corresponding author extends sincere thanks to Dr Hema Rajaram and Mr Akhilesh Potnis, Molecular Biology Division, Bhabha Atomic Research Centre for their help in recording the optical microscopic images.

Open Access This article is distributed under the terms of the Creative Commons Attribution 4.0 International License (http://creativecommons.org/licenses/by/4.0/), which permits unrestricted use, distribution, and reproduction in any medium, provided you give appropriate credit to the original author(s) and the source, provide a link to the Creative Commons license, and indicate if changes were made.

\section{References}

Al-Degs YS, Abu-El-Halawa R, Abu-Alrub SS (2012) Analyzing adsorption data of erythrosine dye using principal component analysis. Chem Eng J 191:185-194. https://doi.org/10.1016/j. cej.2012.03.002

Apostol LC, Pereira L, Pereira R, Gavrilescu M, Alves MM (2012) Biological decolorization of xanthene dyes by anaerobic granular biomass. Biodegradation 23:725-737. https://doi.org/10.1007/ s10532-012-9548-7

Apostol LC, Ghinea C, Alves M, Gavrilescu M (2016) Removal of Erythrosine B dye from water effluents using crop waste pumpkin seed hulls as adsorbent. Desalination Water Treat 57:2258522608. https://doi.org/10.1080/19443994.2015.1132477

Banat IM, Nigam P, Singh D, Marchant R (1996) Microbial decolorization of textile-dyecontaining effluents: a review. Boresour Technol 58:217-227. https://doi.org/10.1016/S0960-8524(96)00113-7

Borzelleca JF, Capen CC, Hallagan JB (1987) Life time toxicity/ carcinogenicity study of FD\&C Red No. 3 (erythrosine) in rats. Food Chem Toxicol 25:723-733. https://doi.org/10.1016/02786915(87)90226-2

Chakraborty S, De S, Das Gupta S, Basu JK (2005) Adsorption study for the removal of basic dye: experimental and modelling. Chemosphere 58:1079-1086. https://doi.org/10.1016/j.chemospher e.2004.09.066

Clarke EA, Anlike R (1980) Organic Dyes and Pigments. SpringerVerlag, Berlin, Handbook of Environmental Chemistry

Copello GJ, Mebert AM, Raineri M, Pesent MP, Diaz LE (2011) Removal of dyes from water using chitosan hydrogel/SiO2 and chitin hydrogel/SiO2 hybrid materials obtained by the sol-gel method. J Hazard Mater 186:932-939. https://doi.org/10.1016/j. jhazmat.2010.11.097

Desiderio C, Marra C, Fanali S (1998) Quantitative analysis of synthetic dyes in lipstick by micellar electrokinetic capillary chromatography. Electrophoresis 19:1478-1483

Freundlich HMF (1906) Over the adsorption in solution. J Phys Chem $57: 385-471$

Gupta VK, Mittal A, Kurup L, Mittal J (2006) Adsorption of a hazardous dye, Erythrosine, over hen feathers. J Colloid Interface Sci 304:52-57. https://doi.org/10.1016/j.jcis.2006.08.032

Ho YS, McKay G (1999) Pseudo-second order model for sorption processes. Process Biochem 34:451-465. https://doi.org/10.1016/ S0032-9592(98)00112-5

$\mathrm{Hu}$ Z, Srinivasan MP (2001) Mesoporous high-surface-area activated carbon. Microporous Mesoporous Mater 43:267-275. https://doi. org/10.1016/S1387-1811(00)00355-3

Ishikawa F, Shigeoka S, Nagashima M, Takahashi M, Kamimura H (2003) Simultaneous determination of eleven dyes and their aluminum lakes in drugs. J AOAC Int 86:215-221

Jain R, Sikarwar S (2009) Adsorptive removal of Erythrosine dye onto activated low cost de-oiled mustard. J Hazard Mater 164:627-633. https://doi.org/10.1016/j.jhazmat.2008.08.043

Karcher S, Kornmüller A, Jekel M (2001) Screening of commercial sorbents for the removal of reactive. Dyes Pigm 51:111-125. https ://doi.org/10.1016/S0143-7208(01)00066-3

Kaur M, Datta M (2013) Adsorption equilibrium and kinetics of toxic dye-Erythrosine B adsorption onto montmorillonite. Sepa Sci Technol 48:1370-1381. https://doi.org/10.1080/01496 395.2012.727939

Lagergren S (1898) About the theory of so-called adsorption of soluble substances. Kungliga Svenska Vetenskapsakademiens Handlingar 24:1-39

Langmuir I (1918) The adsorption of gases on plane surface of glass, mica and platinum. J Am Chem Soc 40:1361-1403. https://doi. org/10.1021/ja02242a004 
Mailman RB, Lewis MH (1987) Neurotoxicants and central catecholamine systems. NeuroToxicol 8:123-139

Mckay G, Blair HS, Gardener JR (1982) Adsorption of dyes on chitin-I: equilibrium Studies. J Appl Polym Sci 27:3043-3057. https://doi. org/10.1002/app.1982.070270827

Mittal A, Mittal J, Kurup L, Singh AK (2006) Process development for the removal and recovery of hazardous dye erythrosine from wastewater by waste materials-bottom ash and de-oiled soya as adsorbents. J Hazard Mater B138:95-105. https://doi. org/10.1016/j.jhazmat.2006.05.038

Mohebbi P, Parvini M, Mousav HZ (2014) Removal of erythrosine dyes from aquatic environment using Ziziphus nummularia kernel. Iran J Energy Environ 5:400-406. https://doi.org/10.5829/idosi .ijee.2014.05.04.08

Namasivayam C, Muniasamy N, Gayathri K, Rani M, Ranganathan K (1996) Removal of dyes from aqueous solutions by cellulosic waste orange peel. Bioresor Technol 57:37-43. https://doi. org/10.1016/0960-8524(96)00044-2

Namasivayam C, Radhika R, Suba S (2001) Uptake of dyes by a promising locally available agricultural solid waste: coir pit. Waste Manag 21:381-387. https://doi.org/10.1016/S0956 $-053 \mathrm{X}(00) 00081-7$

Okoye CC, Onukwuli OD, Okey-Onyesolu CF, Nwokedi IC (2016) Adsorptive removal of Erythrosin B dye onto Terminalia Catappa endocarp prepared activated carbon: kinetics, isotherm and thermodynamics studies. Chem Process Eng Res 43:2224-7467

Ozsoy Y, Araman A (1993) Identification and determination of colorants in chewing gums and jellies. Acta Pharm Turcica 35:33-38

Rani MJ, Murugan M, Subramaniam P, Subramanian E (2016) Study of water soluble dyes adsorption from aqueous solution by Prosopis spicigera L. wood (PSLW) carbon. Indian J Chem Technol 23:22-30

Rozada F, Calvo LF, Garcia AI, Martin-Villacorta J, Otero M (2003) Dye adsorption by sewage sludge-based activated carbons in batch and fixed bed systems. Biores Technol 87:221-230. https://doi. org/10.1016/S0960-8524(02)00243-2

Rytwo G, Huterer-Harar R, Dultz S, Gonen Y (2006) Adsorption of fast green and erythrosin-B to montmorillonite modified with crystal violet. J Therm Anal Calorim 84:225-231. https://doi. org/10.1007/s10973-005-7187-5

Salvi NA, Chattopadhyay S (2017) Biosorption of Azo dyes by spent Rhizopus arrhizus biomass. Appl Water Sci 7:3041-3054. https ://doi.org/10.1007/s13201-016-0417-0

Sasaki YF, Kawaguchi S, Kamaya A, Ohshita M, Kabasawa K, Iwama K, Taniguchi K, Tsuda S (2002) The comet assay with 8 mouse organs: results with 39 currently used food additives. Mutat Res Genet Toxicol Environ Mutagen 519:103-119. https://doi. org/10.1016/S1383-5718(02)00128-6

Sharifzade G, Asghari A, Rajabi M (2017) Highly effective adsorption of xanthene dyes (rhodamine B and erythrosine B) from aqueous solutions onto lemon citrus peel active carbon: characterization, resolving analysis, optimization and mechanistic studies. RSC Adv 7:5362-5371. https://doi.org/10.1039/C6RA23157H

Sharma P, Kaur H (2011) Sugarcane bagasse for the removal of Erythrosin B and methylene blue from aqueous waste. Appl Water Sci 1:135-145. https://doi.org/10.1007/s13201-011-0018-x

Smaranda C, Apostol LC, Petraru M, Caliman FA, Gavrilescu M (2010) Comparative studies concerning the behaviour of organic pollutants in Iai area soil. Lucrări Stiinţifice seria agronomie 53:143-145

Tang ZG, Zhou RQ, Duan ZT (2000) Separation of gibberellic acid (GA3) by macroporous adsorption resins. J Chem Technol Biotechnol 75:695-700. https://doi.org/10.1002/1097-4660(20000 8)75:8\%3c695:AID-JCTB273\%3e3.0.CO;2-V

Tonogai Y, Iwaida M, Tati M, Ose Y, Sato T (1978) Biochemical decomposition of coal-tar dyes II Acute toxicity of coal-tar dyes and their decomposed products. J Toxicol Sci 3:205-214. https:// doi.org/10.2131/jts.3.2051/jts.3.205

Tripathi M, Khanna SK, Das M (2004) A novel method for the determination of synthetic colors in ice cream samples. J AOAC Int 87:657-663

Uysal OK, Aral EC (1998) Teratogenic effects and the role in the etiology of atopic diseases of erythrosine (FD and C Red No. 3) Turkish. J Med Sci 28:363-368

Valliamma S, Subbareddy Y, Nagaraja KS, Jeyaraj B (2015) Adsorption of Erythrosine-B on mesoporous graphitic activated carbon prepared from bael tree (Aeglemarmelos) bark: equilibrium, kinetics and thermodynamic studies. J Mater Environ Sci 6:2836-2852

Virtanen S, Ali-Mattila E, Pekka L (1999) Determination of synthetic colorants and natural carmine in wines. J Int Sci Vigne Vin 33:145-147

Weber WJ, Morris JC (1963) Kinetics of adsorption on carbon from solution. J Sanit Eng Div 89:31-60

Publisher's Note Springer Nature remains neutral with regard to jurisdictional claims in published maps and institutional affiliations.

\section{Affiliations}

\section{Neeta A. Salvi ${ }^{1}$}

Neeta A. Salvi

nasalvi@barc.gov.in

1 Bio-Organic Division, Bhabha Atomic Research Centre, Trombay, Mumbai 400 085, India 